Article

\title{
Effects of Cold Rolling Deformation and Solution Treatment on Microstructural, Mechanical, and Corrosion Properties of a Biocompatible Ti-Nb-Ta-Zr Alloy
}

\author{
Mariana Lucia Angelescu ${ }^{1}$, Alexandru Dan ${ }^{1}$, Elena Ungureanu ${ }^{1} \mathbb{D}$, Nicoleta Zarnescu-Ivan ${ }^{1, *(D)}$ \\ and Bogdan Mihai Galbinasu ${ }^{2}$ (D) \\ 1 Faculty of Materials Science and Engineering, University Politehnica of Bucharest, \\ 060042 Bucharest, Romania; mariana.angelescu@upb.ro (M.L.A.); alexandru.dan0806@upb.ro (A.D.); \\ ungureanu.elena14@yahoo.com (E.U.) \\ 2 Dental Medicine Faculty, University of Medicine and Pharmacy “Carol Davila” Bucharest, \\ 020021 Bucharest, Romania; bogdan.galbinasu@umfcd.ro \\ * Correspondence: nicoleta.zarnescu@upb.ro; Tel.: +40-21-402-95-31
}

Citation: Angelescu, M.L.; Dan, A.; Ungureanu, E.; Zarnescu-Ivan, N.; Galbinasu, B.M. Effects of Cold Rolling Deformation and Solution Treatment on Microstructural, Mechanical, and Corrosion Properties of a Biocompatible Ti-Nb-Ta-Zr Alloy. Metals 2022, 12, 248. https://doi.org/ $10.3390 /$ met12020248

Academic Editors: Antoine Ferreira, Krzysztof Talaśka and

Szymon Wojciechowski

Received: 4 December 2021

Accepted: 25 January 2022

Published: 28 January 2022

Publisher's Note: MDPI stays neutral with regard to jurisdictional claims in published maps and institutional affiliations.

Copyright: (C) 2022 by the authors. Licensee MDPI, Basel, Switzerland. This article is an open access article distributed under the terms and conditions of the Creative Commons Attribution (CC BY) license (https:// creativecommons.org/licenses/by/ $4.0 /)$.

\begin{abstract}
One of the most important requirements for a metallic biomaterial is the mechanical biocompatibility, which means excellent mechanical properties-high strength and fatigue strength, but low elastic modulus, to be mechanically harmonized with hard tissues. In order to improve the mechanical and biocompatible performance of the Ti-25.5Nb-4.5Ta-8.0Zr wt $\%$ alloy, the influence of cold plastic deformation and solution treatment on its properties were investigated. $\mathrm{The} \mathrm{Ti}-25.5 \mathrm{Nb}-$ 4.5Ta-8.0Zr wt \% alloy was fabricated by melting in a cold crucible furnace (in levitation) and then subjected to several treatment schemes, which include cold rolling and different solution treatments. Microstructural and mechanical characteristics of specimens in as-cast and thermo-mechanically processed condition were determined by SEM microscopy and tensile testing, for different structural states: initial as-cast/as-received, cold rolled and solution treated at different temperatures $(800,900$, and $1000{ }^{\circ} \mathrm{C}$ ) and durations $(5,10,15$, and $20 \mathrm{~min}$ ), with water quenching. It was concluded that both cold rolling and solution treatment have important positive effects on structural and mechanical properties of the biomaterial, increasing mechanical strength and decreasing the elastic modulus. Samples in different structural states were also corrosion tested and the results provided important information on determining the optimal processing scheme to obtain a high-performance biomaterial. The final processing route chosen consists of a cold rolling deformation with a total deformation degree of $60 \%$, followed by a solution heat treatment at $900{ }^{\circ} \mathrm{C}$ with maintenance duration of $5 \mathrm{~min}$ and water quenching. By applying this thermo-mechanical processing scheme, the Ti-25.5Nb-4.5Ta$8.0 \mathrm{Zr}$ wt $\%$ alloy showed an elastic modulus of $56 \mathrm{GPa}(5 \%$ higher than in the as-cast state), an ultimate tensile strength of $1004 \mathrm{MPa}(41.8 \%$ higher than in the as-cast state), a yield strength of $718 \mathrm{MPa}(40.6 \%$ higher than in the as-cast state), and increased corrosion resistance (the corrosion rate decreased by $50 \%$ compared to the as-cast state).
\end{abstract}

Keywords: Ti-Nb-Ta-Zr alloy; thermo-mechanical treatment; cold rolling; solution treatment; mechanical properties; corrosion resistance; microstructural characteristics; grain-size distribution

\section{Introduction}

During implant life in the human body, the osseous implant is exposed to high mechanical loads, fatigue loading, friction, and wear. Considering all these requirements, titanium and its alloys are considered the most biocompatible of all metallic biomaterials for implant materials [1-6].

The standard Ti-based biomaterial used in osseous implantology, Ti-6Al-4V alloy, has been shown to have a high elastic modulus (close to $110 \mathrm{GPa}$ ) [1,7-9] and toxic effects due to $\mathrm{Al}$ ions released, associated with long-term health problems like neurological pathologies, 
and due to $\mathrm{V}$ ions release, known to be cytotoxic [1,10,11]. The appropriate alloying elements are selected according to their biocompatibility, cell viability, corrosion resistance, and rate of human allergic reactions to various metallic biomaterials.

Consequently, a new generation of low elastic modulus $\beta$-Ti alloys, containing only $\mathrm{Nb}$, Ta, Zr, has been developed [12-20]. Niobium ( $\mathrm{Nb})$, tantalum (Ta), and zirconium (Zr) are known as the most harmless titanium alloying elements [21-25]. $\mathrm{Nb}$ and Ta are $\beta$ stabilizers and $\mathrm{Zr}$ is important for the solid solution strengthening of the alloy. In the last decades, the properties of new metastable beta $\mathrm{Ti}$ alloys have been intensively studied: Ti-35Nb-7Zr-5Ta [26], Ti-24Nb-4Zr-8Sn [27], Ti-25Ta-25Nb [28], and Ti-20Zr-10Nb [29].

Promising elastic behavior can be achieved in $\beta$-Ti alloys when $\alpha$ "-Ti transformation occurs, due to their low elastic modulus compared to that of the $\beta$-Ti parent phase [30-34]. It has been shown that in Ti-Nb-Ta-Zr (TNTZ) alloys, the proportion of $\alpha^{\prime \prime}$ phases varies inversely with the $\mathrm{Nb}$ content [35].

$\beta$-Ti alloys are also advantageous from the perspective of preventing stress shielding. The key feature of Ti-Nb-Ta-Zr (TNTZ) alloy is represented by the excellent combination of mechanical properties (high strength-low elastic modulus) and its unique compositional design, which ensures a high biocompatibility with human bone due to the use of non-toxic elements (Ti, Nb, Ta, Zr). Considering the demand of an appropriate elastic modulus of $30 \mathrm{GPa}$, in order to avoid the stress shielding effect, which leads to bone atrophy [2-6], it was proven that TNTZ alloy can exhibit an elastic modulus between (45-75) GPa, depending on applied cold-deformation intensity [36]. At the same time, in order for TNTZ alloys to be used in load-bearing applications (such as narrow dental implants), a higher mechanical strength is required, which is also achieved by large plastic deformations, by dislocation and grain boundary strengthening.

Depending on the processing route, containing both cold-deformation and thermal treatments, the elastic modulus of TNTZ or other similar alloys (TZN, TNZ) was drastically influenced [36-44]. If phase changes occur during cold-deformation and/or thermal treatments, the $\beta$-Ti $/ \alpha^{\prime \prime}-\mathrm{Ti}$ phase proportion and characteristics are strongly influenced as-well [38].

Continuing the research carried out in recent years on this category of alloys, the present work aims to investigate the effect of cold deformation and solution treatment on biomechanical properties of newly developed Ti-25.5Nb-4.5Ta-8.0Zr wt\% (TNTZ) alloy, in order to select the optimal thermo-mechanical treatment from the structural, mechanical, and corrosion point of view.

\section{Materials and Methods}

\subsection{Alloy Synthesis and Thermo-Mechanical Processing Route}

The investigated alloy with the nominal chemical composition Ti-25.5Nb-4.5Ta-8.0Zr $\mathrm{wt} \%$ (TNTZ) was obtained by melting in an inert controlled atmosphere (argon), in a cold crucible (in levitation) FIVE CELES-MP25 (Five's Group Company, Paris, France) furnace, starting from high purity elemental components: Ti: $\min .99 .6 \%$, no. GF71176776; Nb: $\min$. 99.9\%, no. GF49338120; Zr: $\min .99 .5 \%$, no. GF10742284; Ta: $\min .99 .9 \%$, no. GF80066392 (SIGMA ALDRICH/MERCH, Merck KGaA, Darmstadt, Germany). In order to obtain a high chemical homogeneity, the re-melting of the ingots was performed twice. The alloy chemical composition was determined by EDS technique, using a scanning electron microscope (SEM), model TESCAN VEGA II-XMU (TESCAN, Brno, Czech Republic), coupled with a BRUKER QuantaxxFlash 6/30 (Bruker Corporation, Billerica, MA, USA) EDS detector.

Figure 1 shows the applied thermo-mechanical processing route (TMP), starting from initial/as-received (AR) TNTZ alloy, which was deformed by cold-rolling (CR), using a Mario di Maio LQR120AS rolling-mill (Mario di Maio Inc., Milano, Italy), with a total reduction ratio (thickness reduction) of approx. $\varepsilon \approx 60 \%$. After $C R$, the samples were solution treated (ST) by heating at 800 (ST1), 900 (ST2), and $1000{ }^{\circ} \mathrm{C}$ (ST3) with variable treatment durations from 5 to $20 \mathrm{~min}$, followed by water quenching (WQ). All ST treatments were 
performed using a GERO SR $100 \times 500$ furnace (Carbolite-Gero, Neuhausen, Germany), under high vacuum.

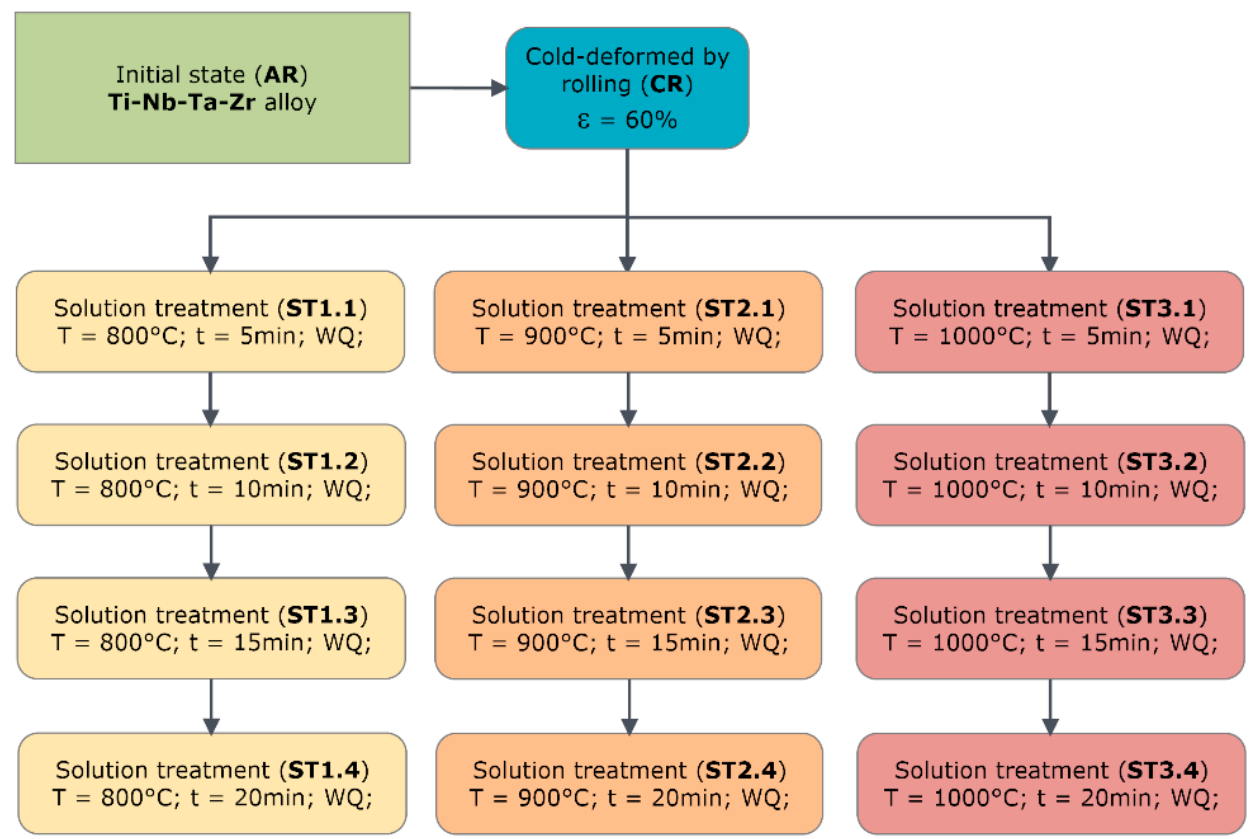

Figure 1. Thermo-mechanical processing scheme applied to Ti-Nb-Ta-Zr alloy (Ti-25.5Nb-4.5Ta$8.0 \mathrm{Zr} \mathrm{wt} \%$ ).

\subsection{Microstructural and Mechanical Characterization}

All microstructural investigations were carried out using an SEM model TESCAN VEGA II-XMU (TESCAN, Brno, Czech Republic) microscope, including grain size measurements, which were performed using a complex image analysis software integrated into the SEM. Samples were cut from all TMP states using precision Metkon MICRACUT 200 (Metkon Instruments Inc., Bursa, Turkey) cutting equipment, fitted with a XDLM (NX-MET, Echirolles, France) diamond cutting disk. All samples were hot mounted in conductive phenolic resin (NX-MET, Echirolles, France) and then polished, using a MetkonDigiprep ACCURA (Metkon Instruments Inc., Bursa, Turkey) machine.

An additional super-polishing step was applied using a Buehler VibroMet2 (Buehler, Lake Bluff, IL, USA) machine, for improving the sample surface quality. The polishing and super-polishing steps of sample preparation are presented in detail in a previous paper [38]. To highlight the microstructure of TNTZ alloy, after the super-polishing step, the samples were etched with an etching solution (Kroll reagent), having the following composition: $6 \mathrm{~mL}$ nitric acid $\left(\mathrm{HNO}_{3}\right)+3 \mathrm{~mL}$ hydrofluoric acid $(\mathrm{HF})+91 \mathrm{~mL}$ water distilled, the etching duration was 40 to $60 \mathrm{~s}$.

Mechanical characterization by tensile tests was performed using a GATAN MicroTest$2000 \mathrm{~N}$ testing machine (Gatan Inc., Pleasanton, CA, USA) with a strain rate of $1 \times 10^{-4} \mathrm{~s}^{-1}$. The tensile test specimens had a "dog-bone" shape, with a calibrated part as follows (Figure 2): $2 \mathrm{~mm}$ width by $0.8 \mathrm{~mm}$ thickness and $7 \mathrm{~mm}$ gauge length. Based on the obtained stress-strain curves, the following mechanical characteristics were: ultimate tensile strength $\left(\sigma_{\mathrm{UTS}}\right)$; yield strength $\left(\sigma_{0.2}\right)$; fracture strain $\left(\varepsilon_{\mathrm{f}}\right)$; and elastic modulus $(\mathrm{E})$. All values were rounded at nearest integer. 


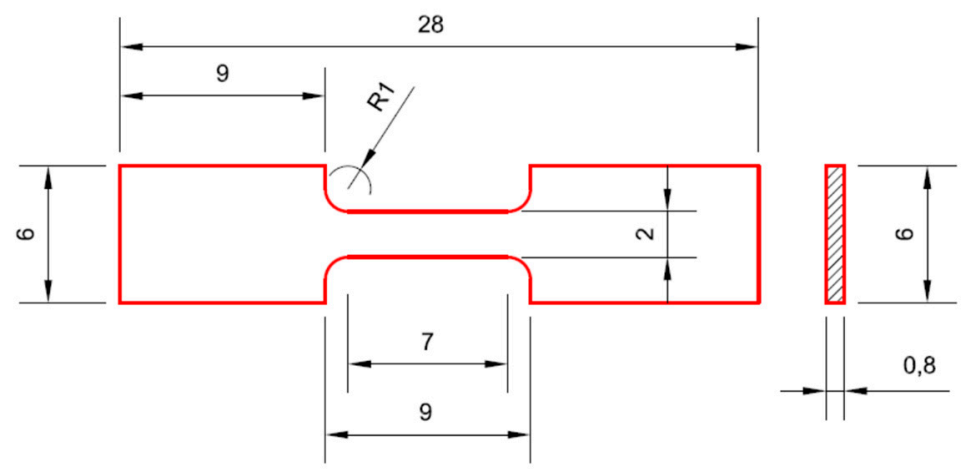

Figure 2. Geometric configuration of samples used in mechanical testing (tensile tests).

\subsection{Corrosion Testing in Simulated Body Fluids (SBF)}

Corrosion testing in simulated body fluids (SBF) was performed on TMP samples showing the best results from a microstructural and mechanical point of view, by the linear polarization technique. This technique consists of drawing linear polarization curves involving the following steps: measuring the open circuit potential (OCP), over a period of $6 \mathrm{~h}$; tracing of potentially dynamic polarization curves from $-0.2 \mathrm{~V}$ (vs. OCP) to $+0.2 \mathrm{~V}$ (vs OCP)—Tafel curves, with a scan rate of $0.167 \mathrm{mV} / \mathrm{s}$.

Corrosion resistance tests were performed using a Potentiostat/Galvanostat PARSTAT 4000 (Princeton Applied Research-AMETEK, Oak Ridge, TN, USA). Corrosion testing was performed according to ASTM G59-97(2014) [45]. An electrochemical cell consisting of a saturated calomel electrode (SCE)—reference electrode, a platinum electrode-recording electrode and the working electrode, which consisted of the investigated samples, were used to perform the tests. The tests were performed at $37 \pm 0.5^{\circ} \mathrm{C}$. The SBF solution had the following composition: $7.996 \mathrm{~g} / \mathrm{L} \mathrm{NaCl}, 0.350 \mathrm{~g} / \mathrm{L} \mathrm{NaHCO}_{3}, 0.224 \mathrm{~g} / \mathrm{L} \mathrm{KCl}, 0.228 \mathrm{~g} / \mathrm{L}$ $\mathrm{K}_{2} \mathrm{HPO}_{4} \cdot 3 \mathrm{H}_{2} \mathrm{O}, 0.305 \mathrm{~g} / \mathrm{L} \mathrm{MgCl} 2 \cdot 6 \mathrm{H}_{2} \mathrm{O}, 40 \mathrm{~mL} 1 \mathrm{M}-\mathrm{HCl}, 0.278 \mathrm{~g} / \mathrm{L} \mathrm{CaCl}_{2}, 0.071 \mathrm{~g} / \mathrm{L}$ $\mathrm{Na}_{2} \mathrm{SO}_{4}, 6.057 \mathrm{~g} / \mathrm{L}\left(\mathrm{CH}_{2} \mathrm{OH}\right)_{3} \mathrm{CNH}_{2}, \mathrm{pH}=7.4$.

\section{Results and Discussion}

\subsection{Chemical, Microstructural, and Mechanical Properties of Initial/As-Received (AR)} TNTZ Alloy

The SEM-EDS technique was used to investigate the chemical composition of initial/asreceived (AR) TNTZ alloy. Figure 3a shows a representative SEM image for the TNTZ alloy in the AR state. Figure $3 b$ shows the maps for the dispersion of the main alloying elements within the structure of the TNTZ (Titanium, Niobium, Zirconium, and Tantalum) alloy. A fine uniform distribution can be observed for all alloying elements, indicating a good chemical homogeneity. No other alloying elements were identified within EDS spectra of initial/as-received (AR) TNTZ alloy (Figure 3c). Table 1 shows the computed global chemical composition. It can be seen that the measured global chemical composition is almost identical with the imposed one, proving that the synthesis in inert controlled atmosphere (argon) by cold crucible induction in levitation is a suitable synthesis technique for titanium-based alloys. 

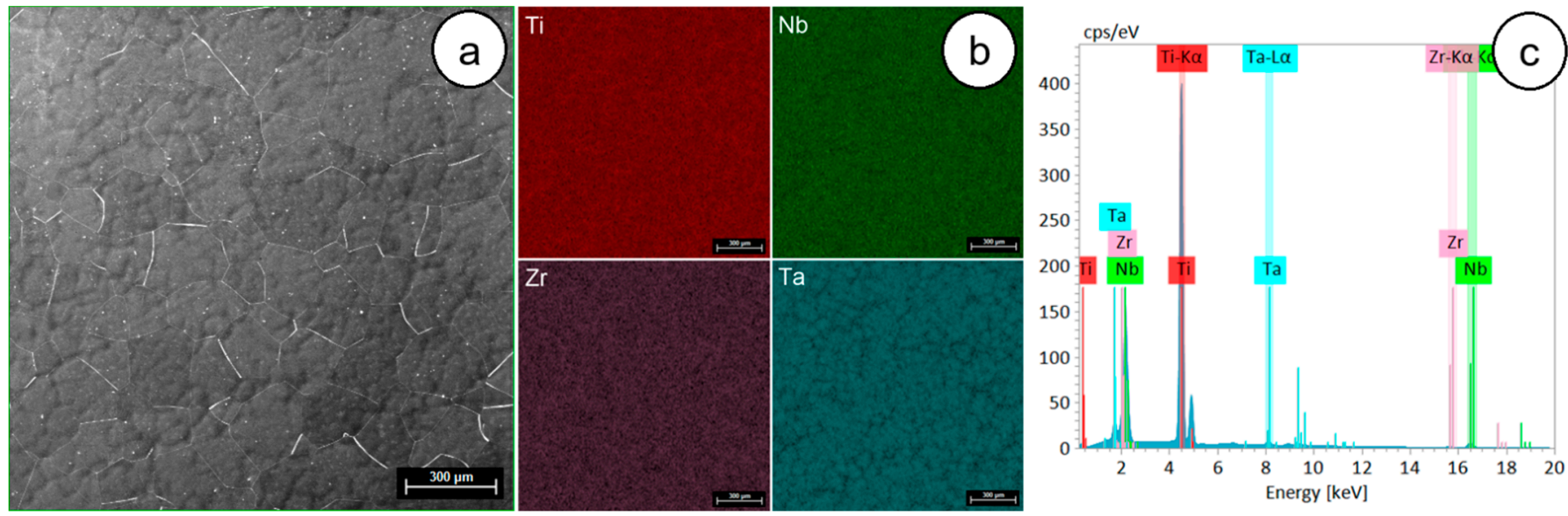

Figure 3. SEM-BSE image of the AR TNTZ alloys microstructure (a); SEM-EDS colorized maps. showing the main alloying elements distribution (b); EDS spectra of AR TNTZ alloy (c).

Table 1. Computed global chemical composition of TNTZ alloy in AR state.

\begin{tabular}{lcccc}
\hline \multicolumn{1}{c}{ Element } & At. No. & Mass, [\% wt.] & Abs. Error, [\%] & Rel. Error, [\%] \\
\hline Titanium & 22 & 62.29 & 1.61 & 2.77 \\
Niobium & 41 & 25.26 & 0.47 & 2.76 \\
Zirconium & 40 & 7.94 & 0.10 & 3.33 \\
Tantalum & 73 & 4.51 & 0.11 & 3.10 \\
\hline Sum & & 100.00 & - & - \\
\hline
\end{tabular}

The microstructure and the grain size distribution of AR TNTZ alloy are shown in Figures 4 and 5 . The microstructure is relatively homogeneous, with equiaxed grains, most of the grains having a grain-size between $100-150 \mu \mathrm{m}$ and an average grain-size close to $141 \mu \mathrm{m}$. The mechanical properties of the AR TNTZ alloy are shown in Table 2.

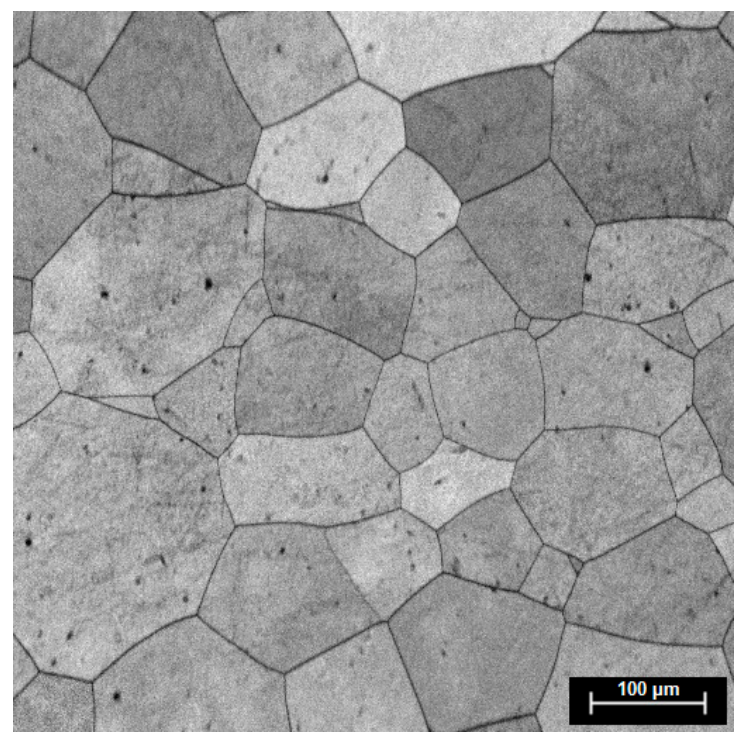

Figure 4. Microstructure of the AR TNTZ alloy. 


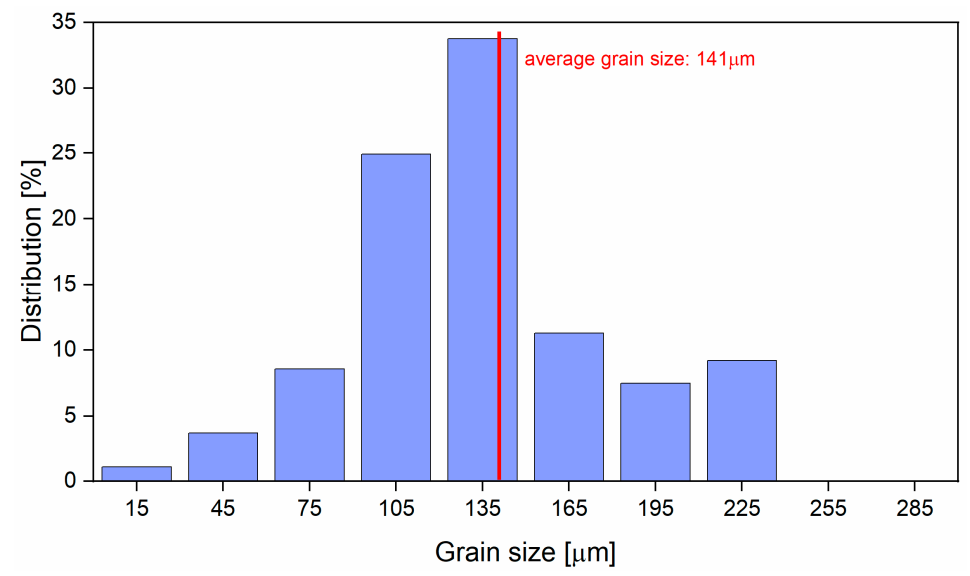

Figure 5. Grain-size distribution in AR TNTZ alloy.

Table 2. Mechanical characteristics of TNTZ alloy in AR state.

\begin{tabular}{|c|c|c|c|c|}
\hline Structural State & $\begin{array}{c}\text { Ultimate Strength, } \\
\sigma_{\text {UTS }}[\mathrm{MPa}]\end{array}$ & $\begin{array}{l}\text { Yield Strength, } \\
\quad \sigma_{0.2}[\mathrm{MPa}]\end{array}$ & $\begin{array}{c}\text { Fracture Strain, } \\
\varepsilon_{\mathrm{f}}[\%]\end{array}$ & $\begin{array}{c}\text { Elastic Modulus, } \\
\text { E [GPa] }\end{array}$ \\
\hline AR TNTZ alloy & $708 \pm 10$ & $512 \pm 13$ & $10 \pm 2$ & $59 \pm 2$ \\
\hline
\end{tabular}

\subsection{Microstructural and Mechanical Properties of Cold-Rolled (CR) TNTZ Alloy}

Figure 6 illustrates the microstructure of the TNTZ alloy, as resulted after the coldrolling deformation (CR), with a total reduction ratio of $60 \%$. The microstructure shows the presence of deformation bands, deformation twins, and dislocation bands, which are well outlined, indicating a high degree of deformation texturing. Also, the microstructure morphology suggests that the mechanisms of deformation are conventional dislocation glide and twinning. Figure 6 shows that no discontinuities are presented in the volume, which demonstrates that the alloy can withstand cold deformations with high reduction ratios (at least 60\%).
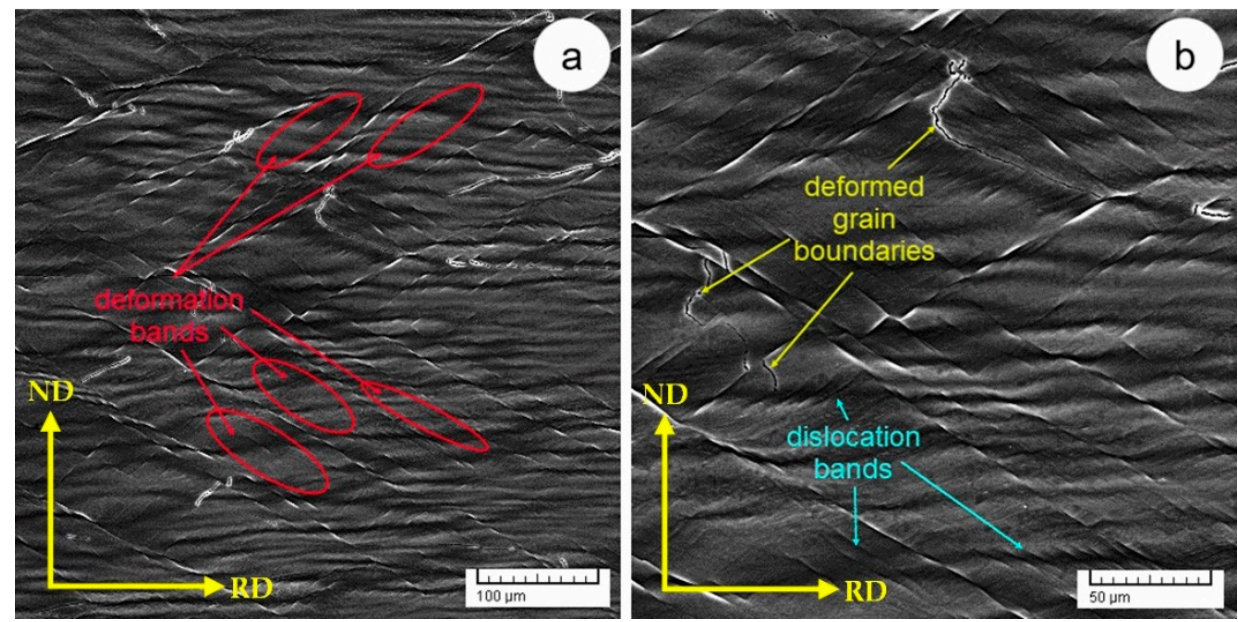

Figure 6. Microstructure of the CR TNTZ alloy at different magnifications $(\times 200-(\mathbf{a}) ; \times 400-(\mathbf{b}))$.

In order to study the evolution of grain deformation degree, the samples were examined in RD-ND cross-section (RD—rolling direction; ND—normal direction) and to emphasize the main microstructural characteristics, only the most representative images were selected.

Table 3 shows the mechanical characteristics of the TNTZ alloy in CR state. It can be observed that after cold rolling, the strain hardening effect is quite strong, increasing 
the strength properties (expressed by the ultimate tensile strength $\sigma_{\text {UTS }}$ and the yield strength $\sigma_{0.2}$ ) and decreasing the ductility (expressed by the fracture strain $\varepsilon_{\mathrm{f}}$ ) compared to initial/as-received (AR) state (Table 2). On the other hand, it can be noted that cold rolling decreases the elastic modulus from 59 to $50 \mathrm{GPa}$, which can be attributed to deformation texture formation. This result also confirms that one of the best ways to increase tensile strength while maintaining a low elastic modulus is to increase the dislocation density into the alloy structure by cold working.

Table 3. Mechanical characteristics of CR TNTZ alloy.

\begin{tabular}{ccccc}
\hline Structural State & $\begin{array}{c}\text { Ultimate Strength, } \\
\boldsymbol{\sigma}_{\text {UTS }}[\mathrm{MPa}]\end{array}$ & $\begin{array}{c}\text { Yield Strength, } \\
\boldsymbol{\sigma}_{\mathbf{0 . 2}}[\mathbf{M P a}]\end{array}$ & $\begin{array}{c}\text { Fracture Strain, } \\
\boldsymbol{\varepsilon}_{\mathbf{f}}[\%]\end{array}$ & $\begin{array}{c}\text { Elastic Modulus, } \\
\text { E [GPa] }\end{array}$ \\
\hline CR TNTZ alloy & $1261 \pm 12$ & $1166 \pm 10$ & $4 \pm 1$ & $50 \pm 3$ \\
\hline
\end{tabular}

\subsection{Microstructural and Mechanical Characteristics Evolution during Solution Treatment of TNTZ Alloy}

In Table 4 are given the grain-size evolutions of TNTZ alloy microstructure during ST treatment performed at different temperatures $\left(800,900\right.$, and $1000{ }^{\circ} \mathrm{C}$, respectively) and variable holding times (5, 10, 15, and $20 \mathrm{~min}$, respectively). All the grain dimensions presented in Table 4 are averaged values obtained from a series of parallel measurements.

Table 4. Grain-size distribution during solution treatment of TNTZ alloy.

\begin{tabular}{ccccc}
\hline & \multicolumn{4}{c}{ Grain-Size $[\boldsymbol{\mu m}]$} \\
\hline \multirow{2}{*}{ Treatment Temperature $\left[{ }^{\circ} \mathbf{C}\right]$} & \multicolumn{5}{c}{ Holding Time [min] } \\
\cline { 2 - 5 } & $\mathbf{5}$ & $\mathbf{1 0}$ & $\mathbf{1 5}$ & $\mathbf{2 0}$ \\
\hline 800 & 43 & 48 & 54 & 62 \\
900 & 57 & 63 & 72 & 79 \\
1000 & 91 & 104 & 117 & 162 \\
\hline
\end{tabular}

Figure 7 illustrates the evolution of the microstructure of the TNTZ alloy as resulted after the solution treatment performed at $800{ }^{\circ} \mathrm{C}$. The microstructure shows the presence of recrystallized $\beta$-Ti phase grains, with and increasing grain-size from $43 \mu \mathrm{m}$ for a treatment duration of $5 \mathrm{~min}$ (Figure 7a), to $62 \mu \mathrm{m}$ for a treatment duration of $20 \mathrm{~min}$ (Figure 7d), showing that the treatment duration moderately influences the increase of grain-size. The same observations can be made in the case of solution treatment performed at $900{ }^{\circ} \mathrm{C}$ (Figure 8), when the grain-size increases from $57 \mu \mathrm{m}$ for a treatment duration of $5 \mathrm{~min}$ (Figure 8a), to $79 \mu \mathrm{m}$ for a treatment duration of $20 \mathrm{~min}$ (Figure 8d). Also, in the case of solution treatment performed at $1000{ }^{\circ} \mathrm{C}$ (Figure 9), one can observe that the grainsize increases from $91 \mu \mathrm{m}$ for a treatment duration of $5 \mathrm{~min}$ (Figure 9a), to $162 \mu \mathrm{m}$ for a treatment duration of $20 \mathrm{~min}$ (Figure $9 \mathrm{~d}$ ). It is obvious that, during solution treatment the most influential factor on grain-size is the heating temperature, since for 20 min treatment duration the grain-size is increasing from $62 \mu \mathrm{m}$ at $800{ }^{\circ} \mathrm{C}$, to $79 \mu \mathrm{m}$ at $900{ }^{\circ} \mathrm{C}$, and to $162 \mu \mathrm{m}$ at $1000^{\circ} \mathrm{C}$. 

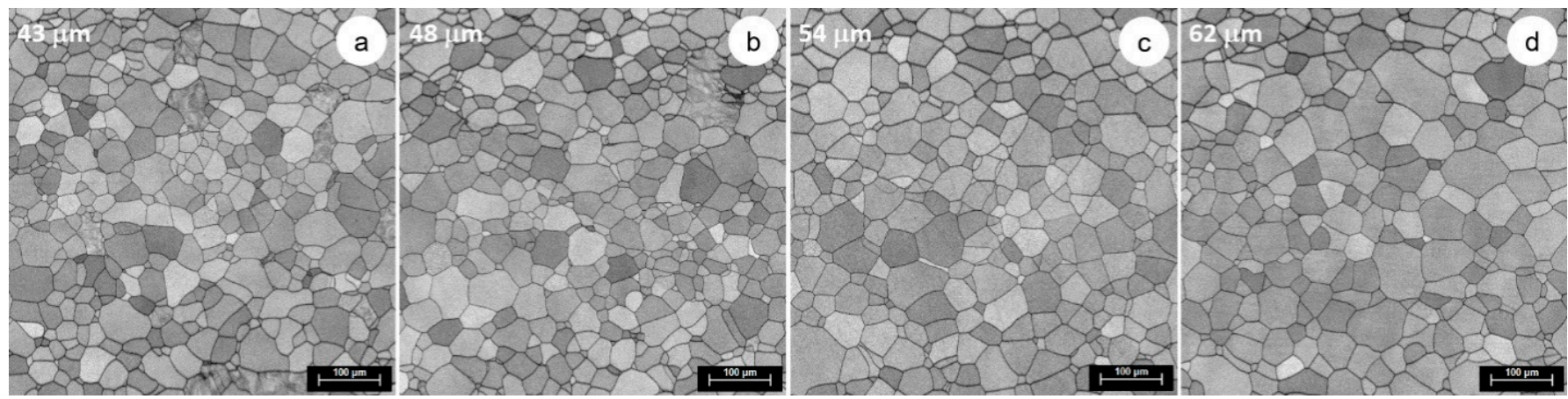

Figure 7. Evolution of the TNTZ alloy microstructure during ST treatment performed at $800{ }^{\circ} \mathrm{C}$ for: 5 min (ST 1.1)—(a); 10 min (ST 1.2)—(b); 15 min (ST 1.3)—(c); 20 min (ST 1.4)—(d).
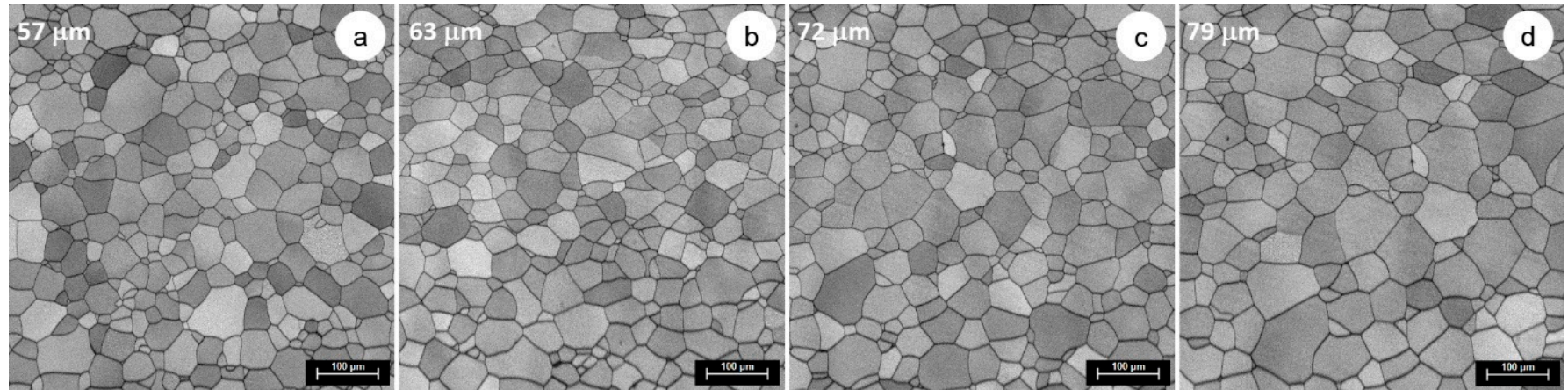

Figure 8. Evolution of the TNTZ alloy microstructure during ST treatment performed at $900{ }^{\circ} \mathrm{C}$ for: $5 \mathrm{~min}$ (ST 2.1)—(a); $10 \mathrm{~min}$ (ST 2.2)—(b); $15 \mathrm{~min}$ (ST 2.3)—(c); $20 \mathrm{~min}$ (ST 2.4)—(d).
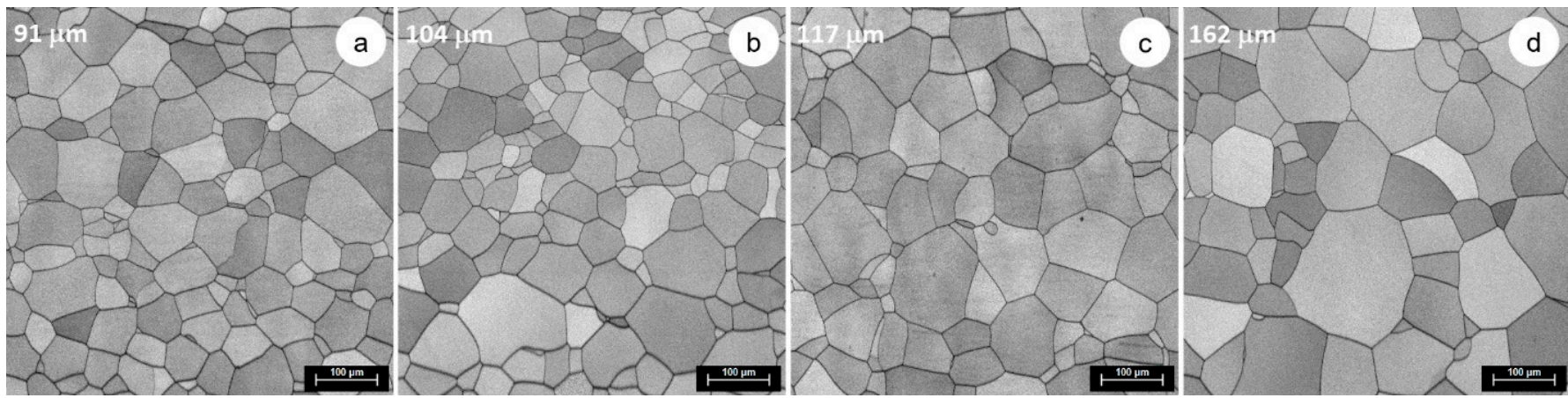

Figure 9. Evolution of the TNTZ alloy microstructure during ST treatment performed at $1000{ }^{\circ} \mathrm{C}$ for: 5 min (ST 3.1)—(a); $10 \mathrm{~min}$ (ST 3.2)—(b); $15 \mathrm{~min}$ (ST 3.3)—(c); $20 \mathrm{~min}$ (ST 3.4)—(d).

A graphical representation of the grain-size evolutions during ST treatment of the TNTZ alloy as a function of holding time and treatment temperature is given in Figure 10, which shows that the grain-size increases with both maintenance time and temperature. The error bars (Figure 10a) represent the standard deviation of grain dimensions obtained from parallel tests. In this graphical representation, it can be seen that the holding time of solid state treatment has less influence on grain-size evolution compared to the treatment temperature. 

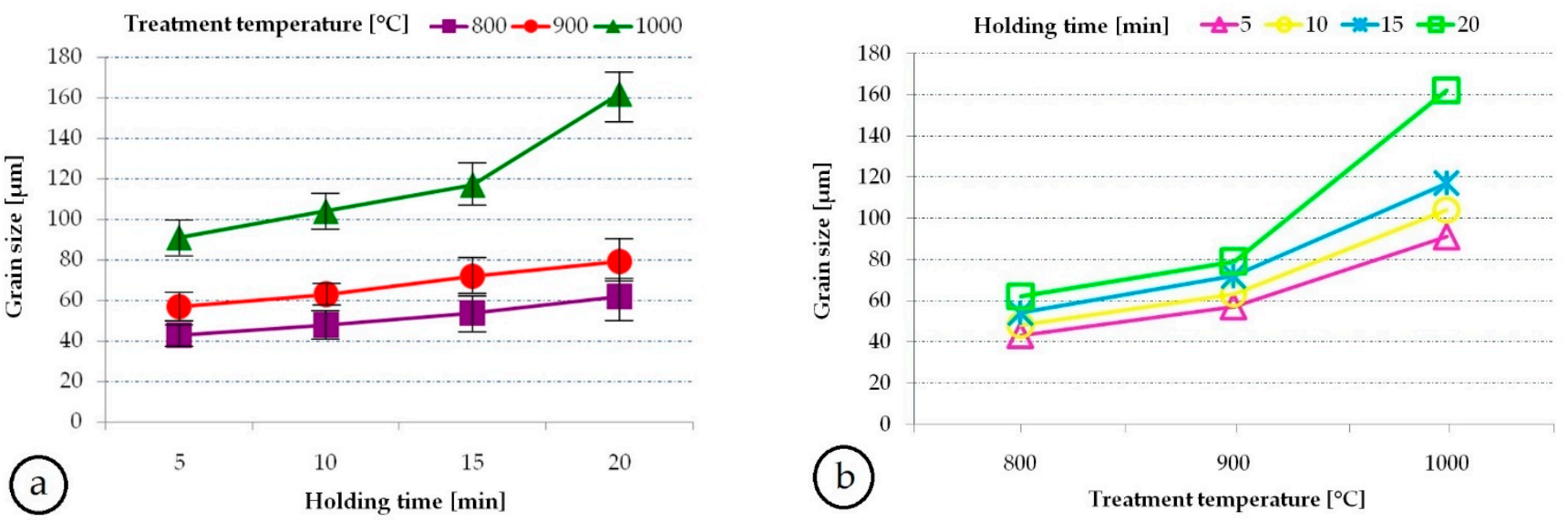

Figure 10. The evolution of grain-size distribution in a TNTZ alloy during ST treatment, as a function of: holding time (a) and treatment temperature (b).

Tables $5-7$ present the mechanical characteristics for the Ti-Nb-Ta-Zr alloy solution treated at 800,900 , and $1000{ }^{\circ} \mathrm{C}$, with variable holding times of 5, 10, 15, and $20 \mathrm{~min}$ Generally, it can be seen that the solution treatment improves the ductility (expressed by the fracture strain $\varepsilon_{f}$ ) and decreases the strength properties compared to those in the CR state (expressed by the ultimate tensile strength $\sigma_{U T S}$ and the yield strength $\sigma_{0.2}$ ), but this influence depends on the temperature and duration of the solution treatment.

Table 5. Mechanical characteristics of TNTZ alloy solution treated at $800{ }^{\circ} \mathrm{C}$ with holding times of: $5 \mathrm{~min}$ (ST 1.1), $10 \mathrm{~min}$ (ST 1.2), $15 \mathrm{~min}$ (ST 1.3), and $20 \mathrm{~min}$ (ST 1.4).

\begin{tabular}{rcccc}
\hline Structural State & $\begin{array}{c}\text { Ultimate Strength, } \\
\boldsymbol{\sigma}_{\text {UTS }}[\mathbf{M P a}]\end{array}$ & $\begin{array}{c}\text { Yield Strength, } \\
\boldsymbol{\sigma}_{\mathbf{0 . 2}}[\mathbf{M P a}]\end{array}$ & $\begin{array}{c}\text { Fracture Strain, } \\
\boldsymbol{\varepsilon}_{\mathbf{f}}[\boldsymbol{\%}]\end{array}$ & $\begin{array}{c}\text { Elastic Modulus, } \\
\mathbf{E}[\mathrm{GPa}]\end{array}$ \\
\hline Solution treated (ST 1.1) & $1166 \pm 10$ & $1052 \pm 12$ & $6 \pm 1$ & $54 \pm 4$ \\
Solution treated (ST 1.2) & $1083 \pm 12$ & $978 \pm 12$ & $7 \pm 1$ & $55 \pm 3$ \\
Solution treated (ST 1.3) & $1034 \pm 13$ & $916 \pm 10$ & $8 \pm 1$ & $55 \pm 4$ \\
Solution treated (ST 1.4) & $997 \pm 11$ & $814 \pm 12$ & $8 \pm 2$ & $54 \pm 4$ \\
\hline
\end{tabular}

Table 6. Mechanical characteristics of TNTZ alloy solution treated at $900{ }^{\circ} \mathrm{C}$ with holding times of: $5 \mathrm{~min}$ (ST 2.1), $10 \mathrm{~min}$ (ST 2.2), $15 \mathrm{~min}$ (ST 2.3), and $20 \mathrm{~min}$ (ST 2.4).

\begin{tabular}{rcccc}
\hline Structural State & $\begin{array}{c}\text { Ultimate Strength, } \\
\boldsymbol{\sigma}_{\text {UTS }}[\mathbf{M P a}]\end{array}$ & $\begin{array}{c}\text { Yield Strength, } \\
\boldsymbol{\sigma}_{\mathbf{0 . 2}}[\mathbf{M P a}]\end{array}$ & $\begin{array}{c}\text { Fracture Strain, } \\
\boldsymbol{\varepsilon}_{\mathbf{f}}[\boldsymbol{\%}]\end{array}$ & $\begin{array}{c}\text { Elastic Modulus, } \\
\mathbf{E}[\mathrm{GPa}]\end{array}$ \\
\hline Solution treated (ST 2.1) & $1004 \pm 11$ & $720 \pm 12$ & $10 \pm 2$ & $56 \pm 4$ \\
Solution treated (ST 2.2) & $944 \pm 10$ & $615 \pm 14$ & $12 \pm 2$ & $55 \pm 2$ \\
Solution treated (ST 2.3) & $863 \pm 12$ & $573 \pm 12$ & $16 \pm 1$ & $55 \pm 4$ \\
Solution treated (ST 2.4) & $767 \pm 11$ & $531 \pm 12$ & $21 \pm 2$ & $56 \pm 3$ \\
\hline
\end{tabular}

Table 7. Mechanical characteristics of TNTZ alloy solution treated at $1000{ }^{\circ} \mathrm{C}$ with holding times of: $5 \mathrm{~min}$ (ST3.1), $10 \mathrm{~min}$ (ST 3.2), $15 \mathrm{~min}$ (ST 3.3), and $20 \mathrm{~min}$ (ST 3.4).

\begin{tabular}{rcccc}
\hline Structural State & $\begin{array}{c}\text { Ultimate Strength, } \\
\boldsymbol{\sigma}_{\text {UTS }}[\mathbf{M P a}]\end{array}$ & $\begin{array}{c}\text { Yield Strength, } \\
\boldsymbol{\sigma}_{\mathbf{0 . 2}}[\mathbf{M P a}]\end{array}$ & $\begin{array}{c}\text { Fracture Strain, } \\
\boldsymbol{\varepsilon}_{\mathbf{f}}[\boldsymbol{\%}]\end{array}$ & $\begin{array}{c}\text { Elastic Modulus, } \\
\mathbf{E}[\mathrm{GPa}]\end{array}$ \\
\hline Solution treated (ST 3.1) & $847 \pm 14$ & $546 \pm 10$ & $13 \pm 2$ & $57 \pm 4$ \\
Solution treated (ST 3.2) & $844 \pm 13$ & $597 \pm 12$ & $9 \pm 2$ & $55 \pm 4$ \\
Solution treated (ST 3.3) & $859 \pm 14$ & $613 \pm 11$ & $5 \pm 2$ & $54 \pm 4$ \\
Solution treated (ST 3.4) & $856 \pm 12$ & $723 \pm 13$ & $5 \pm 2$ & $56 \pm 3$ \\
\hline
\end{tabular}


The solution treatment performed at $800{ }^{\circ} \mathrm{C}$ (Table 5) shows that the increase of treatment duration from 5 (ST 1.1) to $20 \mathrm{~min}$ (ST 1.4) leads to a sharp decrease in strength properties and to a moderate increase in ductility, compared to the CR state. Similar observations can be made in the case of solution treatment performed at $900{ }^{\circ} \mathrm{C}$ (Table 6), with the difference that the ductility increases drastically, the maximum fracture strain (close to $21 \%$ ) being recorded in the case of the sample treated for 20 min (ST 2.4) (Table 6).

In the case of the alloy solution treated at $1000{ }^{\circ} \mathrm{C}$ (Table 7 ), one can observe that the ductility is decreasing with increasing the treatment duration, the minimum fracture strain (close to 5\%) being recorded in the case of sample treated for 20 min (ST 3.4), while the strength properties are maintained at approximately constant values during solution treatment.

Taking into account that the objective of the experiments was to obtain a biocompatible TNTZ alloy with homogeneous, equiaxed structure, and convenient mechanical properties (good ductility, high strength, and low elastic modulus), the TMP schemes consisting of cold deformation followed by solution treatment at $900{ }^{\circ} \mathrm{C}$ (variants ST 2.1-ST 2.4), with water quenching (WQ), can be considered as the most appropriate. In these conditions, the TNTZ alloy presented a fully recrystallized equiaxed microstructure, with an average grain size between 57-79 $\mu \mathrm{m}$, and the best combination of mechanical properties (high strength, good ductility and low elastic modulus); for this reason, these samples were further corrosion tested in SBF.

\subsection{Corrosion Testing of TNTZ Alloy in SBF}

The TNTZ samples showing the best results from microstructural and mechanical point of view (ST 2.1 to ST 2.4) were further tested for corrosion resistance in SBF solution, in order to assess the best candidate as implant material for medical applications. The variation of the open circuit potential $\left(\mathrm{E}_{\mathrm{OC}}\right)$ corresponding to the investigated samples is presented in Figure 11a, and the potentiodynamic curves (Tafel curves) in Figure 11b.
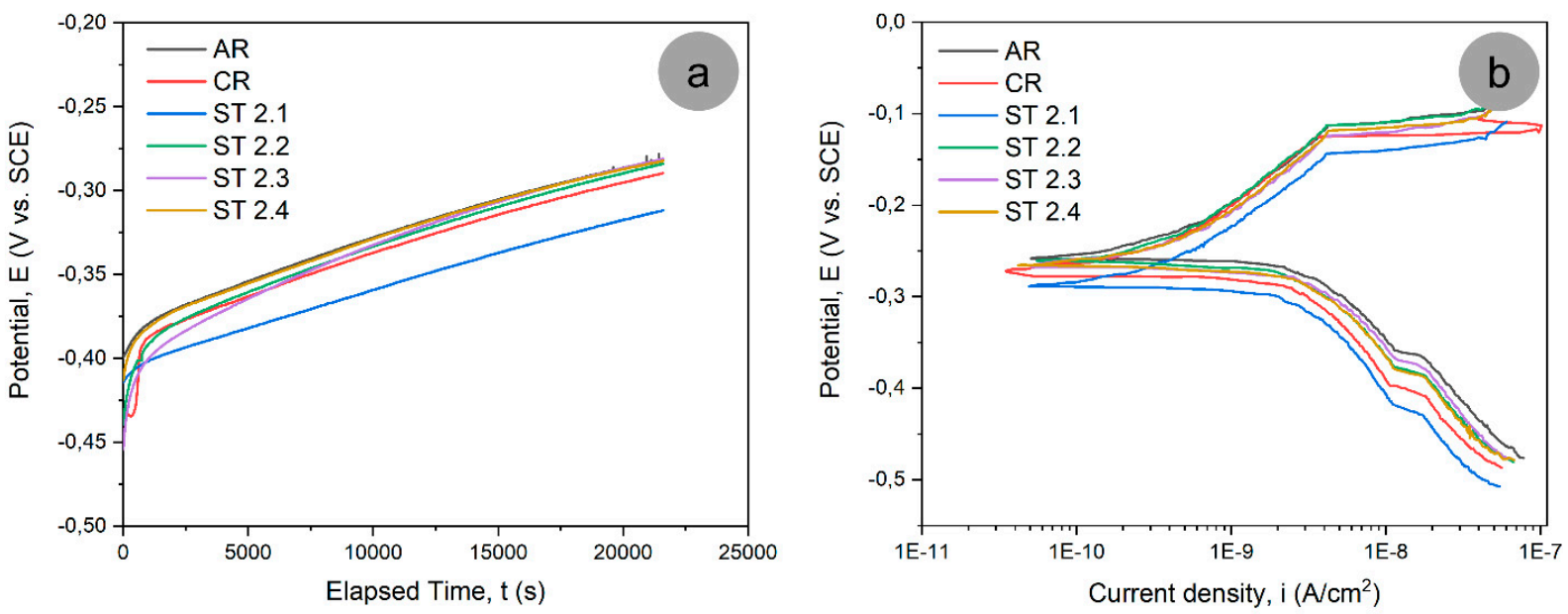

Figure 11. Evolution of the open circuit potential $\left(\mathrm{E}_{\mathrm{OC}}\right)(\mathbf{a})$ and Tafel curves $(\mathbf{b})$ for TMP processed TNTZ alloy.

Using the Tafel curves, the following parameters characterizing the corrosion resistance of the investigated samples were determined: the open circuit potential $\left(\mathrm{E}_{\mathrm{OC}}\right)$; the corrosion potential $\left(\mathrm{E}_{\mathrm{corr}}\right)$; the corrosion current density $\left(\mathrm{i}_{\mathrm{corr}}\right)$; the slope of the cathodic curve $\left(\beta_{\mathrm{C}}\right)$; the slope of the anodic curve $\left(\beta_{\mathrm{a}}\right)$.

Also, with the help of Tafel extrapolation, the polarization resistance was calculated, through which the corrosion resistance can be assessed. The polarization resistance was 
evaluated according to ASTM G59-97(2014), Standard Test Method for Conducting Potentiodynamic Polarization Resistance Measurements [45], using the relation:

$$
R_{p}=\frac{1}{2.3} \cdot \frac{\beta_{a}\left|\beta_{C}\right|}{\beta_{a}+\left|\beta_{C}\right|} \cdot \frac{1}{i_{\text {corr }}}
$$

where:

$\beta_{\mathrm{a}}$-slope of the anodic curve;

$\beta_{C}$-the slope of the cathode curve;

$\mathrm{i}_{\text {corr }}$-the corrosion current density $\left(\mu \mathrm{A} / \mathrm{cm}^{2}\right)$.

The corrosion rate (CR) was calculated according to the standard ASTM G102-89 (2004)e1, Standard Practice for Calculation of Corrosion Rates and Related Information from Electrochemical Measurements [46], using the relation:

$$
\mathrm{CR}=\mathrm{K}_{\mathrm{i}} \cdot \frac{\mathrm{i}_{\text {corr }}}{\rho} \cdot \mathrm{EW}
$$

where:

$\mathrm{Ki}-$ constant that defines the units for the corrosion rate $\left(3.27 \times 10^{-3}\right)$; $\rho$-density $\left(\mathrm{g} / \mathrm{cm}^{3}\right) ; i_{\text {corr }}$-the corrosion current density $\left(\mu \mathrm{A} / \mathrm{cm}^{2}\right)$;

EW—equivalent weight (grams/equivalent).

Table 8 presents the main parameters of the electrochemical corrosion process. It can be considered that the more electropositive values of the open circuit potential ( $\left.\mathrm{E}_{\mathrm{OC}}\right)$ denote a nobler character from the electrochemical point of view. Thus, the ST 2.3 sample, having the most electropositive value $(-280 \mathrm{mV})$, has a better corrosion behavior than the other samples, being closely followed by the AR $(-281 \mathrm{mV})$ and ST $2.4(-282 \mathrm{mV})$ samples.

\begin{tabular}{|c|c|c|c|c|c|c|c|c|}
\hline No. & Sample & $\mathrm{E}_{\mathrm{OC}}(\mathrm{mV})$ & $E_{\text {corr }}(\mathrm{mV})$ & $\begin{array}{c}\mathbf{i}_{\text {corr }} \\
\left(\mathrm{nA} / \mathrm{cm}^{2}\right)\end{array}$ & $\beta_{c}(m V)$ & $\beta_{\mathrm{a}}(\mathrm{mV})$ & $\operatorname{Rp}_{\left(\mathrm{M} \Omega \cdot \mathrm{cm}^{2}\right)}$ & $\begin{array}{c}\text { CR } \\
(\mu \mathrm{m} / \text { year })\end{array}$ \\
\hline 1 & AR & -281 & -258 & 3.141 & 176.66 & 787.94 & 19.975 & 0.0257 \\
\hline 2 & CR & -289 & -274 & 1.368 & 155.81 & 298.67 & 32.544 & 0.0112 \\
\hline 3 & ST 2.1 & -311 & -288 & 1.445 & 165.62 & 244.69 & 29.718 & 0.0118 \\
\hline 4 & ST 2.2 & -284 & -260 & 2.227 & 170.04 & 518.33 & 24.997 & 0.0182 \\
\hline 5 & ST 2.3 & -280 & -267 & 2.252 & 172.20 & 245.81 & 19.550 & 0.0184 \\
\hline 6 & ST 2.4 & -282 & -265 & 2.201 & 170.27 & 428.88 & 24.076 & 0.0180 \\
\hline
\end{tabular}

Table 8. Main corrosion parameters for TMP processed TNTZ alloy.

Considering the value of the corrosion potential $\left(\mathrm{E}_{\mathrm{corr}}\right)$, the higher the electropositive corrosion potential $\mathrm{E}_{\mathrm{corr}}$, the better corrosion resistance; one can observe that the AR sample has the most electropositive $\mathrm{E}_{\text {corr }}$ value $(-258 \mathrm{mV})$, followed by ST $2.2(-260 \mathrm{mV})$, ST 2.4 $(-265 \mathrm{mV})$, and ST $2.3(-267 \mathrm{mV})$ samples. It is known that a low corrosion current density $\left(\mathrm{i}_{\text {corr }}\right)$ indicates a better corrosion resistance. According to this criterion, it can be observed that the lowest value for $\mathrm{i}_{\text {corr }}$ was recorded in the case of CR sample $\left(1.368 \mathrm{nA} / \mathrm{cm}^{2}\right)$, followed by the ST 2.1 sample $\left(1.445 \mathrm{nA} / \mathrm{cm}^{2}\right)$, demonstrating a better corrosion resistance in SBF than the other samples.

Analyzing the polarization resistance, it can be seen that the highest value was obtained in the case of CR sample $\left(32.544 \mathrm{M} \Omega \cdot \mathrm{cm}^{2}\right)$, closely followed by the ST 2.1 sample $\left(29.718 \mathrm{M} \Omega \cdot \mathrm{cm}^{2}\right)$. In terms of corrosion rate, it can be observed that the CR and ST 2.1 samples have registered the smallest values of 0.0112 and $0.0118 \mu \mathrm{m} /$ year, respectively, which represents a decrement of $\sim 50 \%$, in comparison to the value of the AR samples, indicating the beneficial effect of the thermo-mechanical processing.

It is already known that the maximum accepted corrosion rate for implantable materials is $0.13 \mathrm{~mm} /$ year and that the corrosion rate of titanium in passive state is less than $0.02 \mathrm{~mm} /$ year [47-49]. Thus, by comparison, it can be observed that the proposed materials 
have registered values of corrosion rates that are of 1000 times smaller than $0.02 \mathrm{~mm} / \mathrm{y}$, indicating their potential use as implantable biomaterials. Likewise, similar results of the corrosion parameters have also been reported by Surmeneva, M. et al. [26], which have developed a TNTZ alloy by electron beam melting technique.

Overall, the corrosion tests show that the CR sample has higher electrochemical values (it has the lowest corrosion current density, the highest polarization resistance, and the smallest corrosion rate) and thus a better corrosion behavior in SBF than all the other investigated samples, being closely followed by the ST 2.1 sample. Based on the biomechanical properties determined by microstructural, mechanical, and corrosion tests, it can be concluded that the best candidate as an implant material suitable for medical applications is the state ST 2.1, due to the most favorable combination of properties (high values for strength, ductility, and corrosion resistance in SBF and low elastic modulus) compared to all other TMP processed samples.

\section{Conclusions}

- A $\beta$-type Ti-25.5Nb-4.5Ta-8.0Zr wt\%-TNTZ alloy was fabricated by melting in a cold crucible furnace (in levitation) and then subjected to different thermo-mechanical processing schemes (cold rolling and solution treatments), in order to improve biomechanical properties;

- SEM-EDS analysis showed a fine uniform distribution for all alloying elements, indicating a good chemical homogeneity;

- SEM analysis revealed that the microstructure of TNTZ alloy after solution treatment consists of a homogeneous $\beta$-Ti single-phase with equiaxed polyhedral grains and tight grain-size distribution;

- $60 \%$ cold rolling deformation decreased the elastic modulus from 59 to $50 \mathrm{GPa}$, which can be attributed to deformation texture formation;

- During solution treatment the most influential factor on grain-size was the heating temperature;

- TMP schemes consisting of cold deformation, followed by solution treatment at $900{ }^{\circ} \mathrm{C}$ (variants ST 2.1-ST 2.4), with water quenching (WQ), were the most appropriate TMP routes, as the alloy presented a fully recrystallized equiaxed microstructure, with an average grain size between $57-79 \mu \mathrm{m}$, and the best combination of mechanical properties: high strength $\left(\sigma_{\mathrm{UTS}}=767-1004 \mathrm{MPa}\right)$, good ductility $\left(\varepsilon_{\mathrm{f}}=5-13 \%\right)$, and low elastic modulus ( $\mathrm{E}=54-55 \mathrm{GPa})$;

- The corrosion tests show that the cold-rolled sample had higher electrochemical values (the lowest corrosion current density, the highest polarization resistance, and the smallest corrosion rate) and thus a better corrosion behavior in SBF than all the other investigated samples, being closely followed by the sample CR and ST at $900{ }^{\circ} \mathrm{C}$ with a treatment duration of 5 min (ST 2.1) and water quenched (WQ);

- Based on registered biomechanical properties (microstructural, mechanical, and corrosion resistance), the best candidate as implant material for medical applications is the one resulted after a TMP route consisting of a cold deformation (CR) followed by solution treatment (ST) at $900^{\circ} \mathrm{C}$, with a treatment duration of $5 \mathrm{~min}$ (ST 2.1) and water quenching $\left(\sigma_{\mathrm{UTS}}=1004 \mathrm{MPa}, \varepsilon_{\mathrm{f}}=10 \%, \mathrm{E}=56 \mathrm{GPa}\right)$.

Author Contributions: Conceptualization, M.L.A., A.D. and B.M.G.; Methodology, M.L.A. and A.D.; Validation, M.L.A.; Formal analysis, M.L.A.; Investigation, M.L.A., A.D., B.M.G., E.U. and N.Z.-I.; Data curation, M.L.A. and N.Z.-I.; Writing-original draft preparation, M.L.A., A.D. and N.Z.-I.; Writing-review and editing, M.L.A., A.D. and N.Z.-I.; Supervision, M.L.A. All authors have read and agreed to the published version of the manuscript.

Funding: This work was supported by a grant of the Romanian National Authority for Scientific Research, CCCDI-UEFISCDI, Project PN-III-P2-2.1-PED-2019-1915, contract no. 526 PED/23.10.2020, within PNCDI III.

Institutional Review Board Statement: Not applicable. 
Informed Consent Statement: Not applicable.

Data Availability Statement: The data and analysis in this study are available on request from the corresponding author.

Acknowledgments: This work was supported by a grant of the Romanian National Authority for Scientific Research, CCCDI-UEFISCDI, Project PN-III-P2-2.1-PED-2019-1915, contract no. 526 PED/23.10.2020, within PNCDI III.

Conflicts of Interest: The authors declare no conflict of interest.

\section{References}

1. Bălţatu, M.S.; Ţugui, C.A.; Perju, M.C.; Benchea, M.; Spataru, M.C.; Sandu, A.V.; Vizureanu, P. Biocompatible Titanium Alloys used in Medical Applications. Rev. Chim.-Buchar.-Orig. Ed. 2019, 70, 1302-1306. [CrossRef]

2. Piotrowski, B.; Baptista, A.A.; Patoor, E.; Bravetti, P.; Eberhardt, A.; Laheurte, P. Interaction of bone-dental implant with new ultra low modulus alloy using a numerical approach. Mater. Sci. Eng. C 2014, 38, 151-160. [CrossRef] [PubMed]

3. Goshulak, P.; Samiezadeh, S.; Aziz, M.S.R.; Bougherara, H.; Zdero, R.; Schemitsch, E.H. The biomechanical effect of anteversion and modular neck offset on stress shielding for short-stem versus conventional long-stem hip implants. Med. Eng. Phys. 2016, 38, 232-240. [CrossRef] [PubMed]

4. Yamako, G.; Chosa, E.; Totoribe, K.; Watanabe, S.; Sakamoto, T. Trade-off between stress shielding and initial stability on an anatomical cementless stem shortening: In-vitro biomechanical study. Med. Eng. Phys. 2015, 37, 820-825. [CrossRef] [PubMed]

5. Haase, K.; Rouhi, G. Prediction of stress shielding around an orthopedic screw: Using stress and strain energy density as mechanical stimuli. Comput. Biol. Med. 2013, 43, 1748-1757. [CrossRef]

6. Sumner, D.R. Long-term implant fixation and stress-shielding total hip replacement. J. Biomech. 2015, 48, 797-800. [CrossRef]

7. Rahmati, B.; Sarhan, A.D.A.; Zalnezhad, E.; Kamiab, Z.; Dabbagh, A.; Choudhury, D.; Abas, W. Development of tantalum oxide (Ta-O) thin film coating on biomedical Ti-6Al-4V alloy to enhance mechanical properties and biocompatibility. Ceram. Int. 2016, 42, 466-480. [CrossRef]

8. Khanna, R.; Kokubo, T.; Matsushita, T.; Nomura, Y.; Nose, N.; Oomori, Y.; Yoshida, T.; Wakita, K.; Takadama, H. Novel artificial hip joint: A layer of alumina on Ti-6Al-4V alloy formed by micro-arc oxidation. Mater. Sci. Eng. C 2015, 55, 393-400. [CrossRef]

9. Choudhury, D.; Lackner, J.M.; Major, L.; Morita, T.; Sawae, Y.; Bin Mamat, A.; Stavness, I.; Roy, C.K.; Krupka, I. Improved wear resistance of functional diamond like carbon coated Ti-6Al-4V alloys in an edge loading conditions. J. Mech. Behav. Biomed. Mater. 2016, 59, 586-595. [CrossRef]

10. Höhn, S.; Virtanen, S. Effect of inflammatory conditions and $\mathrm{H}_{2} \mathrm{O}_{2}$ on bare and coated Ti-6Al-4V surfaces: Corrosion behaviour, metal ion release and Ca-P formation under long-term immersion in DMEM. Appl. Surf. Sci. 2015, 357, 101-111. [CrossRef]

11. Mohseni, E.; Zalnezhad, E.; Bushroa, A.R. Comparative investigation on the adhesion of hydroxyapatite coating on Ti-6Al-4V implant. Int. J. Adhes. Adhes. 2014, 48, 238-257. [CrossRef]

12. You, L.; Song, X. A study of low Young's modulus Ti-Nb-Zr alloys using electrons alloy theory. Scr. Mater. 2012, 67, 57-60. [CrossRef]

13. Yang, R.; Hao, Y.; Liet, S. Development and application of low-modulus biomedical titanium alloy Ti2448. In Biomedical Engineering, Trends in Materials Science; InTechOpen: London, UK, 2011; pp. 225-248. [CrossRef]

14. You, L.; Song, X. First principles study of low Young's modulus Ti-Nb-Zr alloy system. Mater. Lett. 2012, 80, 165-167. [CrossRef]

15. Karre, R.; Niranjan, M.K.; Dey, S.R. First principles theoretical investigations of low Young's modulus beta Ti-Nb and Ti-Nb-Zr alloys compositions for biomedical applications. Mater. Sci. Eng. C 2015, 50, 52-58. [CrossRef] [PubMed]

16. Liang, S.X.; Feng, X.J.; Yin, L.X.; Liu, X.; Ma, M.; Liu, R. Development of a new beta Ti alloy with low modulus and favorable plasticity for material implant. Mater. Sci. Eng. C 2016, 61, 338-343. [CrossRef]

17. Zhao, X.; Niinomi, M.; Nakai, M.; Ishimoto, T.; Nakano, T. Development of high Zr-containing Ti-based alloys with low Young's modulus for use in removable implants. Mater. Sci. Eng. C 2011, 31, 1436-1444. [CrossRef]

18. Ozan, S.; Lin, J.; Li, Y.; Ipek, R.; Wen, C. Development of Ti-Nb-Zr alloys with high elastic admissible strain for temporary orthopedic devices. Acta Biomater. 2015, 20, 176-187. [CrossRef]

19. Nakai, M.; Niinomi, M.; Zhao, X.; Zhao, X. Self-adjustment of Young's modulus in biomedical titanium alloys during orthopedic operation. Mater. Lett. 2011, 65, 688-690. [CrossRef]

20. Tan, M.H.C. New Generation Titanium Alloys with Low Elastic Modulus for Orthopaedic Implants. Ph.D. Thesis, Flinders University College of Science and Engineering, Bedford Park, Australia, 2018. Available online: https://flex.flinders.edu.au/file/ f544a81b-728f-443d-9263-c29b0944f215/1/ThesisTan2018.pdf (accessed on 3 December 2021).

21. Xie, K.Y.; Wang, Y.; Zhao, Y.; Chang, L.; Wang, G.; Chen, Z.; Cao, Y.; Liao, X.; Lavernia, E.J.; Valiev, R.Z.; et al. Nanocrystalline $\beta$-Ti alloy with high hardness, low Young's modulus and excellent in vitro biocompatibility for biomedical applications. Mater. Sci. Eng. C 2013, 33, 3530-3536. [CrossRef]

22. Li, X.; Chen, T.; Hu, J.; Li, S.; Zou, Q.; Li, Y.; Jiang, N.; Li, H.; Li, J. Modified surface morphology of a novel Ti-24Nb-4Zr-7.9Sn titanium alloy via anodic oxidation for enhanced interfacial biocompatibility and osseointegration. Colloids Surf. B Biointerfaces 2016, 144, 265-275. [CrossRef] 
23. Xue, P.; Li, Y.; Li, K.; Zhang, D.; Zhou, C. Superelasticity, corrosion resistance and biocompatibility of the Ti-19Zr-10Nb-1Fe alloy. Mater. Sci. Eng. C 2015, 50, 179-186. [CrossRef] [PubMed]

24. Stenlund, P.; Omar, O.; Brohede, U.; Norgren, S.; Norlindh, B.; Johansson, A.; Lausmaa, J.; Thomsen, P.; Palmquist, A. Bone response to a novel Ti-Ta-Nb-Zr alloy. Acta Biomater. 2015, 20, 165-175. [CrossRef] [PubMed]

25. Shimabukuro, M.; Ito, H.; Tsutsumi, Y.; Nozaki, K.; Chen, P.; Yamada, R.; Ashida, M.; Nagai, A.; Hanawa, T. The Effects of Various Metallic Surfaces on Cellular and Bacterial Adhesion. Metals 2019, 9, 1145. [CrossRef]

26. Surmeneva, M.; Grubova, I.; Glukhova, N.; Khrapov, D.; Koptyug, A.; Volkova, A.; Ivanov, Y.; Cotrut, C.M.; Vladescu, A.; Teresov, A.; et al. New Ti-35Nb-7Zr-5Ta Alloy Manufacturing by Electron Beam Melting for Medical Application Followed by High Current Pulsed Electron Beam Treatment. Metals 2021, 11, 1066. [CrossRef]

27. Zhang, L.C.; Klemm, D.; Eckert, J.; Hao, Y.; Sercombe, T. Manufacture by Selective Laser Melting and Mechanical Behavior of a Biomedical Ti-24Nb-4Zr-8Sn Alloy. Scr. Mater. 2011, 65, 21-24. [CrossRef]

28. Bertrand, E.; Gloriant, T.; Gordin, D.M.; Vasilescu, C.; Drob, P.; Drob, S. Synthesis and Characterisation of a New Superelastic Ti-25Ta-25Nb Biomedical Alloy. J. Mech. Behav. Biomed. Mater. 2010, 3, 559-564. [CrossRef]

29. Cui, Y.; Li, Y.; Luo, K.; Xu, H.B. Microstructure and Shape Memory Effect of Ti-20Zr-10Nb Alloy. Mater. Sci. Eng. A 2010, 527, 652-656. [CrossRef]

30. Hao, Y.L.; Li, S.J.; Prima, F.; Yang, R. Controlling reversible martensitic transformation in titanium alloys with high strength and low elastic modulus. Scr. Mater. 2012, 67, 487-490. [CrossRef]

31. Hanada, S.; Masahashi, N.; Jung, T.K. Effect of stress-induced $\alpha^{\prime \prime}$ martensiteon Young's modulus of $\beta$ Ti-33.6Nb-4Sn alloy. Mater. Sci. Eng. A 2013, 588, 403-410. [CrossRef]

32. Sadeghpour, S.; Abbasi, S.M.; Morakabati, M. Deformation-induced martensitic transformation in a new metastable beta titanium alloy. J. Alloys Compd. 2015, 650, 22-29. [CrossRef]

33. Elmay, W.; Prima, F.; Gloriant, T.; Bolle, B.; Zhong, Y.; Patoor, E.; Laheurte, P. Effects of thermomechanical process on the microstructure and mechanical properties of a fully martensitic titanium-based biomedical alloy. J. Mech. Behav. Biomed. Mater. 2013, 18, 47-56. [CrossRef] [PubMed]

34. Chen, J.; Ma, F.; Liu, P.; Wang, C.; Liu, X.; Li, W.; Han, Q. Effects of Nb on Superelasticity and Low Modulus Properties of Metastable $\beta$-Type Ti-Nb-Ta-Zr Biomedical Alloys. J. Mater. Eng. Perform. 2019, 28, 1410-1418. [CrossRef]

35. Cojocaru, V.D.; Raducanu, D.; Gloriant, T.; Gordin, D.M.; Cinca, I. Effects of cold-rolling deformation on texture evolution and mechanical properties of Ti-29Nb-9Ta-10Zr alloy. Mater. Sci. Eng. A 2013, 586, 1-10. [CrossRef]

36. Cinca, I.; Nocivin, A.; Raducanu, D.; Gloriant, T.; Gordin, D.M.; Dan, I.; Caprarescu, A.; Cojocaru, V.D. XRD and nano indentation testing of thermo-mechanical processed Ti-29Nb-9Ta-10Zr alloy. Met. Mater. 2015, 53, 17-26. [CrossRef]

37. Tabirca, C.M.; Gloriant, T.; Gordin, D.M.; Thibon, I.; Raducanu, D.; Cinca, I.; Nae, C.I.; Caprarescu, A.; Cojocaru, V.D. Recrystallization temperature influence upon structural changes of $90 \%$ Cold rolled Ti-29Nb-9Ta-10Zr biocompatible alloy. Key Eng. Mater. 2014, 592-593, 370-373. [CrossRef]

38. Nocivin, A.; Raducanu, D.; Vasile, B.; Irimescu, R.; Cojocaru, V.D. Tailoring a low young modulus for a beta titanium alloy by combining severe plastic deformation with solution treatment. Materials 2021, 14, 3467. [CrossRef]

39. Ozan, S.; Lin, J.; Zhang, Y.; Li, Y.; Wen, C. Cold rolling deformation and annealing behavior of a $\beta$-type Ti-34Nb-25Zr titanium alloy for biomedical applications. J. Mater. Res. Technol. 2020, 9, 2308-2318. [CrossRef]

40. Ozan, S.; Lin, J.; Weng, W.; Zhang, Y.; Li, Y.; Wen, C. Effect of thermomechanical treatment on the mechanical and microstructural evolution of a $\beta$-type Ti-40.7Zr-24.8Nb alloy. Bioact. Mater. 2019, 4, 303-311. [CrossRef]

41. Cojocaru, V.D.; Serban, N. Effects of Solution Treating on Microstructural and Mechanical Properties of a Heavily Deformed New Biocompatible Ti-Nb-Zr-Fe Alloy. Metals 2018, 8, 297. [CrossRef]

42. Cojocaru, V.D.; Nocivin, A.; Trisca-Rusu, C.; Dan, A.; Irimescu, R.; Raducanu, D.; Galbinasu, B.M. Improving the Mechanical Properties of a $\beta$-type Ti-Nb-Zr-Fe-O Alloy. Metals 2020, 10, 1491. [CrossRef]

43. Peter, I. Investigations into Ti-Based Metallic Alloys for Biomedical Purposes. Metals 2021, 11, 1626. [CrossRef]

44. Gurau, C.; Gurau, G.; Mitran, V.; Dan, A.; Cimpean, A. The Influence of Severe Plastic Deformation on Microstructure and In Vitro Biocompatibility of the New Ti-Nb-Zr-Ta-Fe-O Alloy Composition. Materials 2020, 13, 4853. [CrossRef] [PubMed]

45. ASTM G59-97; Standard Test Method for Conducting Potentiodynamic Polarization Resistance Measurements. ASTM: West Conshohocken, PA, USA, 2014; 4. [CrossRef]

46. ASTM G102-89 e1; Standard Practice for Calculation of Corrosion Rates and Related Information from Electrochemical Measurements. ASTM: West Conshohocken, PA, USA, 2004; 7. [CrossRef]

47. Bhola, R.; Bhola, S.M.; Mishra, B.; Olson, D.L. Corrosion in titanium dental implants/prostheses-A review. Trends Biomater. Artif. Organs 2011, 25, 34-46.

48. Vijayaraghavan, V.; Sabane, A.V.; Tejas, K. Hypersensitivity to titanium: A less explored area of research. J. Indian Prosthodont. Soc. 2012, 12, 201-207. [CrossRef]

49. Manivasagam, G.; Dhinasekaran, D.; Rajamanickam, A. Biomedical Implants: Corrosion and its Prevention-A Review. Recent Pat. Corros. Sci. 2010, 2, 40-54. [CrossRef] 